821.163.41.09-2:81'38

821.163.41.09-2:81'42

https://doi.org/10.18485/msc.2019.48.1.ch18

\author{
Милка В. НИКОЛИЋ* \\ Универзитет у Крагујевцу \\ Филолошко-уметнички факултет
}

Оригинални научни рад

Примљен: 29. 10. 2018.

Прихваћен: 14. 02. 2019.

\title{
СТИЛИСТИЧКЕ ОДЛИКЕ САВРЕМЕНИХ ДРАМСКИХ ТЕКСТОВА НАСТАЛИХ У РАЗЛИЧИТИМ ДРУШТВЕНИМ КОНТЕКСТИМА**
}

\begin{abstract}
Предмет рада јесу стилистичке одлике савремених драмских текстова насталих у два различита друштвена контекста - Србија и Република Српска. Корпус чине две антологије драмских текстова: (а) Предсмртна младост (Нови Сад, 2006); (б) Драма Републике Српске (Бања Лука, 2011). Циљ је да се испитају језичко-стилска средства која су користили писци стварајући истовремено у различитим околностима. Примењује се лингвостилистички приступ. Долази се до следећих закључака: (а) антологија Предсмртна младост - употребљава се лексика урбаних идиома и једноставна синтакса својствена свакодневној конверзацији; стилистичке доминанте су базиране на социолекту; одступања од традиционалне структуре драмског текста остварују се брисањем формалне границе између дидаскалија и дијалога; (б) антологија Драма Републике Српске - употребљава се лексика својствена свакодневној конверзацији; у појединим текстовима јављају се синтаксичке конструкције са лексичким спојевима несвојственим свакодневној конверзацији; у појединим текстовима говор је маркиран у погледу регионалне, националне или верске припадности; увек се формално раздвајају дидаскалије и говор ликова, али постоје одступања од примарне функције дидаскалија.

Кључне речи: језичко-стилске одлике, драмски текст, контекст, говор ликова, дидаскалија.
\end{abstract}

\section{1. Увод}

Предмет овог рада јесу стилистичке одлике српских драмских текстова насталих карајем двадесетог и почетком двадесет првог века, у два различита друштвена контекста - у Србији и Републици Српској. Корпус чине текстови из двеју антологија:

*milkanik75@gmail.com

** Овај рад написан је у оквиру пројекта Динамика структура савременог српског језика (2011-2019), број 178014, који финансира Министарство просвете, науке и технолошког развоја Републике Србије. 
(а) Антологија Предсмртна младост (Нови Сад, 2006) - обухвата седам дела: Београдска трилогија Биљане Србљановић, Павиљони Милене Марковић, North Force Милене Богавац, Велика бела завеpa Димитрија Војнова, Hadersfild Угљеше Шајтинца, Half Lajf Филипа Вујошевића, Помораниина кора Маје Пелевић;

(б) Антологија Драма Републике Српске (Бања Лука, 2011) - обухвата шест дела: Ноћ пуног мјесеца Јована Спрема, Немири и снови младог Андрића Ранка Рисојевића, Пада киша... јагодо Бранка Бајовића, Шехити у Душановом изарству Ненада Тадића, Хамлет у рајској долини Српске Ранка Симовића, Балон од камена Радмиле Смиљанић.

Циљ је да се применом лингвостилистичког приступа издвоје и опишу језичко-стилска средства која су користили писци стварајући истовремено у различитим околностима. Очекивано је: (а) да ће се у драмским текстовима на почетку новог миленијума, независно од контекста, појавити специфичности на плану односа ауторског говора (дидаскалије, ремарке) и говора ликова; ${ }^{1}$ (б) да ће разлике у друштвеном контексту утицати на сагледавање стварности и донекле на избор језичких средстава приликом обликовања драмског текста. ${ }^{2}$

\section{2. Приступ проблему}

У приступу језику драмских текстова насталих карајем прошлог и почетком овог миленијума треба узети у обзир следеће:

(a) Лингвостилистички приступ пружа увид у један од језичких аспеката драмског текста. ${ }^{3}$ У савременим стилистичким истраживањима драмског дискурса инсистира се на примени сложеног „разгранатог модела" интердисциплинарног типа (уп. Катнић Бакаршић 2003: 12-13).

(б) Према савременим схватањима позоришне уметности, текст је само један од елемената позоришног комада, а његова улога не посматра се као примарна. Наиме, „редитељ није дужан да буде драматург, нити да смишља режију на подлози читања текста”, него „може [...]

\footnotetext{
${ }^{1}$ У савременим драмским текстовима јавља се „криза драмске форме”, и то у четири кључна елемента традиционалне драме: фабула, лик, дијалог, однос сцена-сала (в. Саразак 2009: 19). У српској драматургији јављају се преображаји на три равни: миметичкој, културолошкој и поетичкој (в. Јованов 2006). О лингвостилистичким одликама савремених драмских текстова, в. Николић 2012; Николић 2016.

${ }^{2} \mathrm{O}$ томе како се стварност одражава у драмским делима српских писаца с краја двадесетог века, в. Јакшић Провчи 2007.

${ }^{3}$ Примењујемо поставке теорије интегралне стилистике, која подразумева да се анализом обухватају сва језичка средства са стилогеном вредношћу - како стилематичка, тако и нестилематичка средства (в. Ковачевић 2017: 57-58).
} 
да се користи текстом као материјалом како би створио представу која своје значење не црпе само из текста" (Дипон 2011: 174).

Како се објашњава у лингвистичкој литератури, драма приказује „дијалог у акцији” (Кристал 1995: 97). Другим речима, драма је презентација директне интеракције лицем у лице, ма како да је стилизована форма у којој се то догађа (Шваниц 2000: 92). Дијалог у драми има сличности са природним дијалогом, чиме се постиже уверљивост вербалне интеракције. Међутим, претварање драмског дијалога у конверзацију довело би до деструкције на естетском плану. „Ако се говор ограничи на уравнану ниску разину 'стварног' разговора, драматичар ће наићи на тешкоће ако усхтје продријети имало дубље под саму површину карактера и ситуације" (Кориган 1971: 18).

У традиционалном приступу драми, ремарке се посматрају као текст са инструктивном функцијом (намењен редитељу и глумцима), док се дијалогу приписује поетска функција (Лешић 2008: 388). Међутим, текстови у саставу нашег корпуса показују да овакво схватање треба преиспитати. Писци одустају од структурне и функционалне диференцијације дидаскалија и дијалога, а у језичком обликовању дидаскалија примењују стилематичке поступке какви се очекују у уметничком тексту. У савременој анализи позоришних остварења, појам поетично користи се „у уском значењу које не одговара целокупној организацији сценског писма, већ само његовој строго 'поетској' страни у смислу који Јакобсон даје поетској функцији оријентисаној на организацију саме поруке" (Иберсфелд 2000: 46).

У складу с наведеним, у овом раду разматрамо: (1) однос ауторског говора (дидаскалије, ремарке) и говора ликова; (2) избор и употребу језичких средстава код писаца који стварају у различитим друштвеним контекстима.

\section{3. Разултати анализе}

\section{1. Антологија Предсмртна младост}

Међу седам драма у антологији Предсмртна младост (2006), шест драма има диференциран, а једна има недиференциран дијалог од дидаскалија.

Урбаним идиомима уноси се ниски стил у драмски текст. Како показују наредна четитри одломка, јављају се различите друштвене групе: криминалци са перифирије велеграда; фудбалски навијачи; корисници виртуелних мултимедијалних игара; обожаваоци разних популарних музичких праваца. У лексичкој оскудности и синтаксичкој једноставности говора ових јунака, као и затворености групе која се служи сопственим идиомом, одражавају се границе света у којем јунаци егзистирају:

\footnotetext{
${ }^{4}$ У књизи Аристотел или вампир западног позоришта, Флоранс Дипон указује да „позориште нема ништа са књижевношћу” (2011: 176), као и да треба одбацити схватање о примарној улози текста у настанку позоришне представе (2011: 9-10).
} 
(1) ДАЧА: Шо да ми је напорно? Није Дача сиса. [...] Купио ми чале кадилак за роџендан. Па ме послао у Ел Еј код тетке, да пробам машину. [...] Ша је било брате? Ша ти није јасно? [...] Де си пошо, брате? А? На Дачу си натрчо, је ли? Па је л' ти знаш, мајмуне, да сам ја земунска школа? Знаш ти шта је то? Ја знам ко сам и одакле потичем. Ја бре свако лето, једва чекам кад ћу да палим код деде и бабе, да видим екипу, да се дружим. Да научим шта је живот, да проживим. Не да ми се затре корен, да заборавим које сам семе (Б. Србљановић, Београдска трилогија, 52).

(2) СКАР: Сви знамо ко је започео рат.. Навијачи! Разумеш? А ово сад све дрогирано, и глупо, кеве ми. Једино старија генерација... Дује и ја. То вреди од North Forca. Ови клинци данас, зарађују на нашој слави. Озбиљно, бреее... Па, како? Мислиш да је то мени драго да кажем?! Није ми драго, брате. Али да се кладимо да ови клинци иду на Север због кинте. Па, да. Обрнеш неку гудру, нешто продаш, ово-оно, а још кад имаш неког јаког иза себе... Ја мрзим продају, брате. А ови клинци би данас продали и Звезду и другове, и кеву и ћалета, бре, и све што хоћеш... (М. Богавац, North Force, 91)

(3) КРИВИ: Каунтер Страјк није само компјутерска игра. То је стил живота. Стил живота у коме у сваком моменту мораш да гледаш да ли ти неко прилази иза леђа. Ако хоћеш да будеш први Каунтераш, мораш да знаш неке ствари. Тачније, многе. На пример, како се пуца из обичног пиштоља, па из хеклера... Из снајпера. Из калашњикова. Како се користи нож. Мораш да знаш како се брзо стиже до њихове базе. Мораш да знаш како се поставља бомба. Мораш да знаш како да се сакријеш да те нико не види и онда само да излетиш и све их поубијаш. [...] Мораш да научиш да разумеш шта значи када ти компјутер каже: Enemy spotted. Када компјутер каже: Cover me. Када компјутер каже: Fire in the hole (Ф. Вујошевић, Halflajf, 203).

(4) ЛУИС: Слушај даље. Ганс ен Роузис, последњи изданак лосанђелеског глем хард рока. Почетком деведесетих више не стоји њихова мачо поза. „Гефен” има најјачи алтернативни бенд - Соник Јут. Играју на карту разарања хард рок мита док је још јак. Не успева им. Пробају неке софт варијанте са Енглезима, рецимо Стоун Роузис, ни то не успева. Али, Соник Јут их доводи ди Нирване! Ганси бивају бачени у ђубре а бела деца пројектују муку у Нирвану (Д. Војнов, Велика бела завера, 138).

Језик јунака ових драма - „промишљено оскудан и огољен, генерацијски шифрован и жесток” - представља „њихово једино неотуђиво власништво, њихов свет” (Језеркић/Јованов 2006: 8). Говор ликова јесте кључни доказ њиховог постојања, а припадност одређеној социјалној групи представља једини показатељ идентитета.

Интеракција између ликова у драмама одликује се агресијом, али и отуђеношћу. Ово се најбоље запажа у дијалозима у којима учествују чланови породице. Породица је у већини драма дезинтегрисана, тако да се појављују само деца или један родитељ са дететом:

(5) САҢА: Што ниси нашао неку бољу, ако ти ја не ваљам, је ли!!! Шта, имао си шта да понудиш, од животног простора - пространи двособни стан на сунчаном Бановом брду, кева као бонус дође за џабе. У већој соби, наравно. Од превозног средства, свакодневна вожња црвеним мерцедесом ГСБ-а, која нуди дружење, нова познанаства, чисту авантуpy...

МИЛОШ: А што ти нешто ниси понудила?

САЊА: Ја? А чији тата је, молим те, платио карте довде? Да није можда твој?

МИЛОШ: Није.

САЊА: И ко је дао лову за прво време, ко? Да ниси можда ти?

МИЛОШ: Нисам. Твој ћале је све платио.

САњА: Тако је, он је све платио!!!

МИЛОШ: Је л' сад у реду?

САЮА: Није у реду!... И није он за тебе ћале. Он је мој отац. Нећу да чујем да га зовеш ћале (Б. Србљановић, Београдска трилогија, 52). 
(6) ЛЕПА: Хоћеш да једеш?

КНЕЗ: Јок, ти ћеш... А кафу си ми скувала, Лепа, са водом којом переш судове, [псовка], хоћеш да ме отрујеш... Ћутиш, ћутиш, али трујеш.

ЛЕПА: Ево...

КНЕЗ: Ево... Ево... Лепина гибаница, слинавица такозвана, направљена од онога што не може да се баци јер није за бацање а као да јесте... Ти, бре, у питу стављаш директно из помијаре а себи правиш другу питу, [псовка], доста ми је што те гледам... А моја Зора је кувала купус, бре, да мирише ко торта а гибаницу - да је тражиш од златне рибице [псовка] (М. Марковић, Павиљони, 60).

(7) РАША: 'Оћеш кафу?

ОТАЦ: Коју кафу?! Ти мене у мојој кући нудиш кафом?! [псовка] Ти мене нудиш мојом кафом?! Овде је све моје, разумеш?! Шта си ти [псовка] створио?

РАША: Ништа.

ОТАЦ: Молим?!

РАША: Кажем, ништа нисам створио.

ОТАЦ: Нећу више да те видим овде, је л' јасно?! Кад се вратим, да те нема, је л' јасно?! Иди, вуци се, сналази се... Где су кључеви од аута?

Раша устане, дода Оиу кључ.

ОТАЦ: Идем да продам ауто! Шта је било?! Мој је! (У. Шајтинац, Hadersfild, 150).

Драма Помораниина кора Маје Пелевић показује највећа одступања од традиционалне драмске форме: (а) у појединим деловима драме долази до интерференције говора аутора и говора ликова; (б) дидаскалије су обликоване стилемима који се базирају на избору лексике, као и на графичком и синтаксичком маркирању; (в) смењују се различите форме казивања - дијалог, монолог, нарација, дескрипција и коментар. Наводимо монолог са почетка драме:

(8) ОНА: Толико волим себе да не мора нико да ме воли.

Лажем.

Волим себе.

Лажем.

Толико волим себе.

Лажем.

Толико волим себе да волим себе.

Лажем.

Да бих волела себе.

Лажем.

Да нико не би морао да ме воли. [...]

Људи воле туђе изнутрице избљувотине њима се хране уживају једу живо месо и не питају се чије је нити одакле долази рад екстремитета производи ултимативно задовољство ослобађање енергије и стимулисање акупунктурних тачака зато што морам и зато што ми је потребно и зато што зато што и зато што сору раste и добићеш две стране јер живимо у ери рециклирања и све је бесмислено и логика је недавно нестала јер је нестала потражња за истом и продају се туђе тротоарске избљувотине као када пљунете на асфалт да то нико не примети јер је ипак срамота и то ОНда ту остане тај шлајм и преноси се са ципеле на ципелу и то ме тако радује јер је остало само кОНструкција, деструкција (М. Пелевић, Поморанцина кора, 229).

На почетку монолога делови реченица написани су у посебним редовима, што се може схватити као поступак појачавања паузе, али и као врста графостилема. Посебан тип графостилема јавља се у речима са различитим типом слова. Поједини делови реченица су интонационо осамостаљени у по- 
себан исказ (парцелација). Трећи стилематички поступак јесте понављање делова реченице. Монолог се завршава пародијом тока свести - искази су без интерпункцијских знакова, садржај је алогичан.

У ремаркама се појављују прво и друго граматичко лице, тј. одступа се од трећег граматичког лица, као у све три ремарке у наредном одломку. Поред тога, друга дидаскалија онеобичава се поступком интонационог издвајања (Играш. Заводљиво. Деструктивно по юега), а трећа графостилемом и експресивним питањима (ОН је шокиран. Зашто? ОН одлази. Да ли ће се вратити?):

(9) Ти си у клубу. Има пуно људи. Не осећаш ништа. Мислиш да не осећаш ништа, а знојиш се.

OHA: Xej!

OH: Xej!

ОНА: Је л' се забављаш?

OH: Axa.

Играш. Заводљиво. Деструктивно по њега.

ОНА: Је л' ти ОНо риба?

OH: Axa.

OHA: Axa, axa, axa.

ОН: Молим?

OНА: Ништа, само ме страшно пали то што причаш. [...]

ОН је шокиран. Зашто? ОН одлази. Да ли ће се вратити? Не. Ти си у клубу. Има пуно људи. Не осећаш ништа. Мислиш да не осећаш ништа, а знојии се.

OHA: Xej!

OH: Је л' се знамо?

OHА: Могуће. [...]

Одмахујем главом. Он одлази у масу. Нема га (М. Пелевић, Помораниина кора, 230-231)

Наредни одломак остварен је помоћу елемената електронске комуникације. Идеја која се сугерише овим поступком јесте да човек може наћи на интернету све што му је потребно и зато не мора ни да размишља ни да осећа:

(10) File

Open

- DOBAR DAN

Edit

Sellect all

Copy

Paste

Budilnik

- Отворити очи. Добродошли у реалан свет. Погледати на сат. Шест часова, нула минута, нула секунди. 000000000000000000... Затворити очи.

Budilnik (М. Пелевић, Поморанцина кора, 236).

Употреба инфинитива у овом одломку представља поступак којим се појачава ефекат отуђености и обезличености човека који механички обавља свакодневне активности ослањајући се на интернет. Говор лика је потпуно дезинтегрисан. 


\section{2. Антологија Драма Републике Српске}

У нашем корпусу, код писаца Републике Српске постоји већа разноврсност изражајних средстава у говору ликова, при чему не долази до интерференције дидаскалија и дијалога. ${ }^{5}$ У свих шест текстова сврстаних у антологију Драма Републике Српске (2011), дијалог и дидаскалије су формално диференцирани.

Ови писци настоје да пренесу природну конверзацију, истичући говорне карактеристике ликова, што се запажа у гласовном склопу речи у и избору лексике:

(11) ЂЕД: Ђе ћеш ти с том флашом?

БАБА: Ја реко' да се не грије...

ЂЕД: Вратиде је. И немој ми сад телалити ту о болестима, о љекарима... Ја откад сам крено по болницама и почо пити љекове, ја се отад пошо разбољевати. Они да шта знају продужили би себи живот, је л’ тако, Драганџа?! (Р. Смиљанић, Балон од камена, 328)

У следећим примерима говор ликова маркиран је територијално и конфесионално, што се уочава на фонетском и лексичком плану:

(12) ПИњО: Ја сан овди на задатку. Овај је бија прави профешур док није пропива. [...] Дозволите да Вам придржин кофере. Ја сан Пињо. Особно сам обрадован ћа сте се вратили у родно мисто. И ја би се вратија кад би смија (Р. Симовић, Хамлет у рајској долини Српске, 273).

(13) ХАЏИЈА: Јах... то ја и велим... добра вакта ко образа нејма... Пуно је фукаре што ће полетит да се награби... А фукара не мере водит државу... [...] шта ће пусти инсан, да не умре мор'о би цркнути!? Полахко, велим... не мере прије зоре сванути... (Б. Бајовић, Пада киша... јагодо, 186)

У драмском тексту „свакодневна конверзација [je] компримирана и интензивирана” (Катнић Бакаршић 2003: 40). Писци одређеним поступцима истичу оно што је битно за смисао драме. Доминантни поступци се могу разврстати у две супротстављене групе - поетизација и иронизација.

Поетизација говора ликова спроведена је преко стилематичких конструкција које у погледу избора лексике и неочекиваних лексичких спојева одступају од свакодневне конверзације, што показују следећи одломци:

(14) ДЈЕВОЈКА: Не, не, мајко, мада твоја тужна благост са стрепњом о смрти говори, ипак, схвати ме да сам премлада за сличне мисли. Из мојих груди сваки сумрак се отаче. Чим гране сунце, пјесма ми се у срце врати с даном што се опет дани; јер нека чудновата свјетлост драга ми срце и слаже нешто топло на дно омекшале душе. Тако и давни трагови случајнога трња утрну пред радошћу што трепери у маглини груди. Око мене посвуд теку зраци и веселост... Па, гдје и како, о мила мајко, да о смрти било шта знам; кад жуђеним жаром удишем дрхтаје драгости и чисти ми поглед тражи љепоту и усхит видика омамног прољећа? (Ј. Спремо, Ноћ пуног мјесеиа, 64)

(15) МЛАДИЋ: (милујући јој косу) Срце бих ишчупао из својих груди, жиле бих посјекао да ми крв из њих пропишти; све бих учинио да будеш увијек моја.

\footnotetext{
${ }^{5}$ Позоришна уметност Републике Српске развија се у специфичном друштвеном контексту. $\mathrm{C}$ једне стране, постоји неопходност очувања сопственог културног идентитета, а с друге, потреба за уклапањем у развојне токове у региону и у свету (Симовић 2011: 45).
} 
ДЈЕВОЈКА: (стискајући га) Бићу! Бићу!

МЛАДИЋ: (тужно) Колико? Наши су дани одбројани. О, горког ли бестражја, запретеног у нашим очевима, мајкама, браћи и... И чему јек љубави, сањиви пелуд или његов узлед? Позни поздрав смрћу нам се руга. Пред рубом памети свака нада већ је болом учворена (Ј. Спремо, Ноћ пуног мјесеиа, 71).

Овакав поступак доследно је спроведен у драми Ноћ пуног мјесей Јована Спрема, а у складу је са историјском епохом у којој се радња догађа, тематиком и свечаним тоном трагедије. Драма приказује трагичну судбину младића и девојке из сукобљених породица растављених крвном осветом у средњовековној Босни.

Иронизација се испољава у различитом ступњу, зависно од предмета на који се односи и од амбијента у коме се радња одвија. Под иронијом подразумевамо не само стилску фигуру, него и поглед на свет који се одликује дистанцом према ономе о чему се говори. Иронични искази су стилски ефектнији ако су формирани као афоризми:

(16) ЧЕРИНА: [...] Што штудирате, Иво?

АНДРИЋ: Ништа што би вас занимало. Природословни-математички одсјек Мудрословног. Бескичмењаци су у првом плану (Р. Рисојевић, Немири и снови младог Андpuћa, 155).

(17) ТАСЛАК: Немам ја ништа против [Филипа] Вишњића. Нема веће комедије од Марка Краљевића и Мусе Кесаџије.

КЕПО: Море, Марко, не ори друмова, море, Турци, не газте орања. Живио потурица!

МАЧАК: [...] Овдје ти једино пролази мулти... мултикултура. Преведено на нашки ово прво значи посипање пепелом, ама ми није јасно шта им је ово друго.

ПИњО: Мултикултура је са наглсаком на мулти [...]. То ти дође у култури, ка шумећи витамини у животу (Р. Симовић, Хамлет у рајској долини Српске, 279).

Најјачи ефекат ироније постигнут је у драми Шехити у Душановом ияарству Ненада Тадића, јер се иза наизглед базазлених исказа крије најсуровије понашање предратних пријатеља једних према другима. Иронија наредних одломака открива се у контексту драме - јунакиња Мира-Емира Југослављев заробљена је од стране својих предратних суседа, који је сада назменично свакодневно злостављају:

(18) ДУШАН: Е моја Миро, што ти је живот. Да није рата, не би човјек упознао комшије, упитао за здравље... [...]

МИРА-ЕМИРА: Кад оно преклане опет прокламоваше крај рата, баш сам се понадала да ће ово да се смири. Да није вас и комшије Дине, давно бих отишла одавде... (Н. Тадић, Шехити у Душановом цุарству, 224).

(19) МИРА-ЕМИРА: Морала бих сада поћи. Превела сам оно за комшију Душана... што вам је требало...

ДИНО: Нећемо сад о послу... Него остани још мало, знаш да је вани сад опасно, свашта има... А ни чарапе ниси навукла... Алија, помози госпођи Југослављев у другој соби...

МИРА-ЕМИРА: Не бих ја... ако се баш не мора...

ДИНО: Мора се, коно. Ни ја не бих штошта, али морам. [...] (Н. Тадић, Шехити у Душановом иарству, 234). 
Дидаскалије наведене уз говор ликова не мењају своју примарну (инструктивну) улогу, али у појединим случајевима одликују се истакнутом поетском функцијом језика. Наредне ремарке из драме Ноћ пуног мјесеца Јована Спрема могу се посматрати као уметнички текст:

(20) ИСТОВРЕМЕНО СЕ ЂУЛИЈА КИКОЋЕ И ПОКАЗУЈЕ ИГРАЧИЦАМА РУДАНА, КОЈИ КАО ОМАЪИЈАН, ЗАБЕЗЕКНУТО ГЛЕДА У СВОГ НЕБЕСКОГ АНЪЕЛА И... КИСНЕ (Ј. Спремо, Ноћ пуног мјесеща, 92).

(21) ПИСАК ЗУРЛЕ. БУБАњ СТАДЕ, ПА СЕ НАНОВО ОГЛАСИ. И СВЕ ЈАЧЕ: КАО КРОЗ СЛУШАЛИЦЕ - КРВОТОК! (Ј. СПремо, Ноћ пуног мјесеща, 101)

(22) БУБЊЕВИ - КРВОТОК САСВИМ ИЗ ДАљИНЕ. РИТМИЧКИ УДАРИ СЕ ПРИБЛИЖАВАЈУ И ПОСТАЈУ СВЕ ЈАЧИ. (Свјетлост се полако гаси.) (Ј. Спремо, Ноћ пуног мјесеия, 107)

У овим дидаскалијма јављају се следећа стилематичка средства: прекид говора обележен тротачком (апосиопеза); интонационо издвајање обележено цртом, двотачким и тачком; екскламација; аорист; графостилеми (велика слова). Конституише се „нека врста жанровски хибридног текста”, у коме равноправно учествују дијалошки дискурс и трансцендирајући наратор који исказује ремарке (Јелушић 2007: 160).

Највиши степен удаљавања од инструктивне функције ремарки остварен је у драми Шехити у Душановом цзарству Ненада Тадића. Наводимо одломке из списка лица и из дидаскалије са почетка драме:

(23) ЛИЦА:

ДУШАН ВУЧИНА - српски ветеран, власник више одликовања, као и свих станова и душа у улазима од 1 до 13 фазе Ц

ДИНО ПУШКАР - предратни комшија и ортак Душанов, живи шехит и власник свих станова и душа у улазима од 15 до 28 фазе Ц

АМИЛА ПУШКАР - кћи Динина, радница у канцеларији УН, у журби и у трећем мјесецу..

МИРА-ЕМИРА ЈУГОСЛАВЉЕВ - једини станар неутралног улаза број 14 фазе Ц

ИСМАИЛ ФЕЛИПЕ ЏОНСОН - начелник зоне безбједности, елегантан и арогантан, укратко - у границама хуманитарне мисије... (Н. Тадић, Шехити у Душановом ияарcmвy, 219).

\section{(24) ОПШТА ДИДАСКАЛИЈА}

Радња се дешава у фази Ц зоне безбједности.

У становима, односно привременим „оперативним центрима” Вучине и Пушкара, чија унутрашњост је мање више иста - прогушено свјетло - дар УН, разуђен намјештај (види се да га нико није хтио), прозори закуцани даскама, понека улазна врата (што свједочи да су бивши станари лијепо испраћени), и обавезне мапе зоне на голим зидовима.

У подруму, гдје се чувају, али и губе, глава и новац, те, као што ће се видјети, историја потврђује опаску да је курва.

У стубиштима, гдје млади нараштај води љубав али и завјереничке разговоре.

На крововима пуним антена - предратних, ратних и посљератних, док падају звијезде, а комшије удишу свјеж ваздух (Н. Тадић, Шехити у Душановом изарству, 220).

Захваљујући стилистичким средствима, наведене ремарке се приближавају уметничком тексту. Поетска функција језика долази до изражаја у следећим поступцима: паралелизам синтаксичких структура; понављање; интонационо издвајање; бинарне напоредне конструкције са семантички неуобичајеним спојевима јединица. 


\section{4. Закључак}

Лингвостилистичка анализа српских драмских текстова насталих на прелазу векова, у два различита друштвена контекста - показује следеће:

(a) Антологија Предсмртна младост - (1) употребљава се лексика урбаних идиома и једноставна синтакса својствена свакодневној конверзацији; (2) стилистичке доминанте су базиране на социолекту; (3) одступања од традиционалне структуре драмског текста остварују се брисањем формалне границе између дидаскалија и дијалога, што доводи до својеврсне интерференције између говора аутора и говора ликова.

(б) Антологија Драма Републике Српске - (1) употребљава се лексика својствена свакодневној конверзацији; (2) у појединим текстовима јављају се синтаксичке конструкције са лексичким спојевима несвојственим свакодневној конверзацији; (3) у појединим текстовима говор је маркиран у погледу регионалне, националне или верске припадности; (4) увек се формално раздвајају дидаскалије и говор ликова, али постоје одступања од примарне функције дидаскалија, остварена тако што се дидаскалије језички обликују као уметнички текст (са истакнутом поетском функцијом језика).

Заједничка одлика свих текстова јесте крајње самосвесно и функционално коришћење језика, које превазилази раван уобичајеног средства карактеризације.

\section{ИЗВОРИ}

Драма Републике Српске, Р. Симовић (прир.) Бања Лука: Арт принт, 2011. Predsmrtna mladost, Antologija najnovije srpske drame (1995-2005), Knj.1, V. Jezerkić, S. Jovanov (prir.), Novi Sad: Sterijino pozorje, 2006.

\section{ЛИТЕРАТУРА}

Дипон 2011: F. Dipon, Aristotel ili vampir zapadnog pozorišta, Beograd: Clio. Иберсфелд 2000: A. Ibersfeld, Ključni termini pozorišne analize, Beograd: CENPI. Језеркић/Јованов 2006: V. Jezerkić, S. Jovanov, Najnovija srpska drama: dva pogleda, $u$ : V. Jezerkić, S. Jovanov (prir.), Predsmrtna mladost, Antologija najnovije srpske drame (1995-2005), Knj.1, Novi Sad: Sterijino pozorje, 5-8.

Јакшић Провчи 2007: Б. Јакшић Провчи, Одраз стварности у делима драмских писаца с краја XX века, Научни састанак слависта у Вукове дане, $36 / 2,465-474$.

Јелушић 2007: S. Jelušić, Prometejev pad. Intertekstualnost: drama, teatar, film, Cetinje: FDU. 
Јованов 2006: S. Jovanov, Ugodne ravnoteže, opasna obećanja (Nova srpska drama 1995-2005), Sarajevske sveske, 11-12. http://www.sveske.ba/bs/content/ ugodne-ravnoteze-opasna-obecanja. 01. 06. 2018.

Катнић Бакаршић 2003: M. Katnić Bakaršić, Stilistika dramskog teksta, Zenica: Fondacija za izdavaštvo FBH.

Ковачевић 2017: М. Ковачевић, Српски језик под лупом науке, Београд: Завод за уџбенике.

Кориган 1971: R. W. Corrigan, Obnova teatra, $u$ : T. Sabljak (ur.), Teatar XX stoljeća, Zagreb: Matica hrvatska, 5-20.

Кристал 1995: D. Kristal, Kembrička enciklopedija jezika, Beograd: Nolit.

Николић 2012: М. Николић, Стилистика дидаскалија у савременој српској драми, у: М. Ковачевић (ур.), Српски језик, књижевност уметност. Структурне карактеристике српског језика, Крагујевац: ФИЛУМ, 357-367.

Николић 2016: М. Николић, Језичко-стилске одлике савремених српских драмских текстова који одступају од традиционалне драмске форме, $y$ : Ж. Чолакова (ур.), Паисиеви четения, Пловдив: Филологически факултет, 264-277.

Лешић: Z. Lešić, Teorija književnosti, Beograd: Službeni glasnik.

Саразак 2009: Ž. P. Sarazak i sar. (prir.), Leksika moderne i savremene drame, Vršac: Književna opština.

Симовић 2011: Р. Симовић, Драма Републике Српске - један могући поглед, y: Р. Симовић (прир.), Драма Републике Српске, Бања Лука: Арт принт, $7-45$.

Шваниц 2000: D. Schwanitz, Teorija sistema i književnost. Nova paradigma, Zagreb: Naklada MD.

Milka V. Nikolić

\section{THE STYLISTIC CHARACTERISTICS OF THE CONTEMPORARY DRAMATIC TEXTS CREATED IN DIFFERENT SOCIAL CONTEXTS}

Summary

The subject of this paper is the stylistic characteristics of the texts created in two different social contexts (Serbia and Republic of Srpska). The aim is to analyze the differences between the linguostylistic devices. Linguo-stylistics approach is applied in the analysis. The conclusion is: (a) the texts created in Serbia have the following characteristics: lexis of urban idioms; simple syntax common for everyday conversation; digressions from traditional structure of dramatic writing is achieved by erasing the formal boundary between didascalies and characters' speech; (b) the texts created in Republic of Srpska have the following characteristics: lexis common for everyday conversation; syntactic constructions with lexical linkers common for a poetic text; didascalies are always formally defined from characters' speech; there are digressions from primary function of didascalies. One thing in common for all texts is that the use of linguo-stylistic devices transcends the usual way of characterization. dascaly.

Keywords: the linguo-stylistic characteristics, dramatic writing, context, characters' speech, di- 